\title{
STUDIES ON CRESCENTIC FRACTURES AND CRESCENTIC GOUGES WITH THE HELP OF CLOSE-RANGE PHOTOGRAMMETRY
}

\author{
By THEODOR WINTGES
}

(Fachhochschule München, D-8000 München 2, West Germany)

\begin{abstract}
Studies on crescentic fractures and crescentic gouges were carried out in the central part of the Alpine piedmont glaciation and the Quaternary Alpine mountain ice sheet. The test sites were situated in the pro-glacial area of the Hornkees south Berliner Hütte (Oberer Zemmgrund, Zillertal, Tyrol, Austria). This is also the area of the former confluence with another glacier which flowed at about $90^{\circ}$ to Hornkees during the late-glacial period. It was therefore possible to make a comparison between different older glacier systems, different flow directions, and different ice thicknesses. About 12000 minor features were measured by close-range photogrammetry; the result was 240 pairs of stereophotographs which were interpreted on first-order equipment. The single forms were registered point by point by coordinates. It was therefore possible to obtain threedimensionally registered forms. One important result was that the late-glacial and the post-glacial glaciers of the Zemmgrund produced minor features with a large variation in size. A further result was the definition of possible glacier-flow directions by interpretation of the different directions of crescentic fractures and crescentic gouges. By this means it was possible to obtain several working reconstructions of the late- and post-glacial stream lines of the merged glaciers.
\end{abstract}

RÉsumé. Étude des fentes de pression et des coups de gouge en croissant à l'aide de la photogrammétrie rapprochée. Des études sur les fentes de pression et coups de gouges en croissant ont été menées dans la partie centrale de la glaciation alpine de piémont et de la calotte glaciaire quaternaire des Alpes. Les zones test sont situées dans la zone proglaciaire du Hornkees, au sud de la Berliner Hütte (Oberer Zemmgrund, Zittertal, Tyrol, Autriche). C'est aussi la zone de l'ancienne confluence avec un autre glacier qui s'écoulait perpendiculairement au Hornkees durant la dernière période glaciaire. Ceci rend possible la comparaison entre différents systèmes glaciaires, différentes directions d'écoulement, et différentes épaisseurs de glace. Environ 12000 formes de détail ont été mesurées

\section{INTRODUCTION}

It is now about 100 years since Chamberlin (1888) described arched cracks and fractures in the decimetre size range. He had found these forms on glacially moulded rock surfaces.

These forms of glacial erosion were first classified by Gilbert (1906) and Ljungner (1930) (cf. Wintges and Heuberger, 1980[a], p. 12 and 13): crescentic fractures, crescentic gouges, and lunate fractures (Sichelwannen).

I have investigated more closely a special form of stria, which I called "combined" striae. These combined striae have already been described by Hillefors $(1968$, p. 323). Extended work on forms of glacial erosion have been undertaken by Harris (1943), Johnson (1976), Schulz (1962, 1967), Schwarzbach (1978), and Rastas and Seppälä (1981). These works give detailed descriptions and hypothetical interpretations of the origin of these forms. Important conclusions drawn from all these observations are: par photogrammétrie rapprochée et 240 couples de stéréophotos ont été interprétés sur un équipement de ler ordre. Les formes individuelles ont été enregistrées point par point en coordonnées. Nous avons ainsi été en mesure d'enregistrer des formes tridimentionelles. Un résultat important est que les glaciers tardi et post glaciaires de Zemmgrund ont produit des formes d'abrasion de tailles très variées. On a également pu définir les directions d'écoulement de la glace à partir des différentes directions des coups de gouge et des fentes de pression et obtenir plusieurs hypothèses de travail sur les lignes de courant des glaciers confluents pendant les périodes tardi et post glaciaires.

Zusammenfassung. Untersuchung von Parabelrissen und Sichelbrüchen mit Hilfe der Nah-Photogrammetrie. Die Arbeiten an Parabelrissen und Sichelbrüchen wurden in einem zentralen Bereich der alpinen Gebirgsvergletscherung und des alpinen eiszeitlichen Eisstromnetzes durchgeführt. Die Testflächen lagen im Gletschervorfeld des Hornkeeses südlich der Berliner Hütte (Oberer Zemmgrund/Zillertal/ Tirol/Österreich). Dies ist ausserdem der Bereich der früheren Konfluenz mit einem anderen Gletscher, der wăhrend des Spătglaziales etwa rechtwinklig zu der Richtung des Hornkeeses floss. So war es möglich, verschieden alte Gletschersysteme, unterschiedliche Fliessrichtungen und Eisdicken miteinander zu vergleichen. Etwa 12.000 Kleinformen wurden mittels Nahbereichsphotogrammetrie vermessen, wobei das Resultat 240 Paare von Stereophotos waren, die an einem Auswertegerăt I. Ordnung ausgewertet wurden. Die einzelnen Formen wurden punktweise mit Koordinaten registriert. Damit waren die Formen dreidimensional erfasst. Ein wichtiges Ergebnis war die Tatsache, dass die spät- und postglazialen Gletscher des Zemmgrundes Formen mit variierenden Grössen produziert haben. Ein weiteres Ergebnis war die Feststellung möglicher Richtungen des Gletscherflusses aus den verschiedenen Orientierungen der Parabelrisse und Sichelbrüche. Auf diese Weise ergaben sich mehrere Arbeitshypothesen für den Verlauf der Stromlinien der vereinigten Gletscher im Spăt- und Postglazial.

a. The parabola which describes a crescentic fracture trends against the ice-flow direction (in the test area, reversal forms are also known).

b. The parabola which describes a crescentic gouge trends towards the glacier-flow direction (in the test area, no reversal forms are known).

c. The straight line (b) which is normal to the length (l) - maximum extension - assists in the interpretation of the reconstruction of former glacier-flow directions (cf. Figs $10 \mathrm{a}$ and $\mathrm{b}$, and $11 \mathrm{a}$ and $\mathrm{b}$ ).

Thus, these minor features allow the interpretation of former directions of glacier flow.

The above-mentioned works dealt without exception with areas of the former North American and northern European continental glaciation. The research area of the 


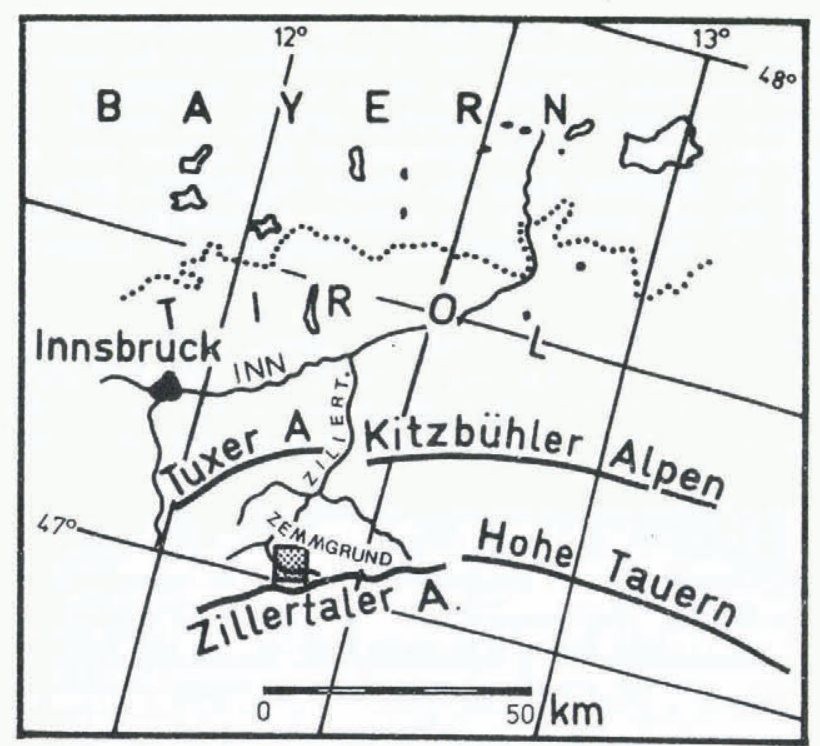

Fig. 1. Outline map of the investigation area, Zemmgrund, Zillertal, Tyrol.
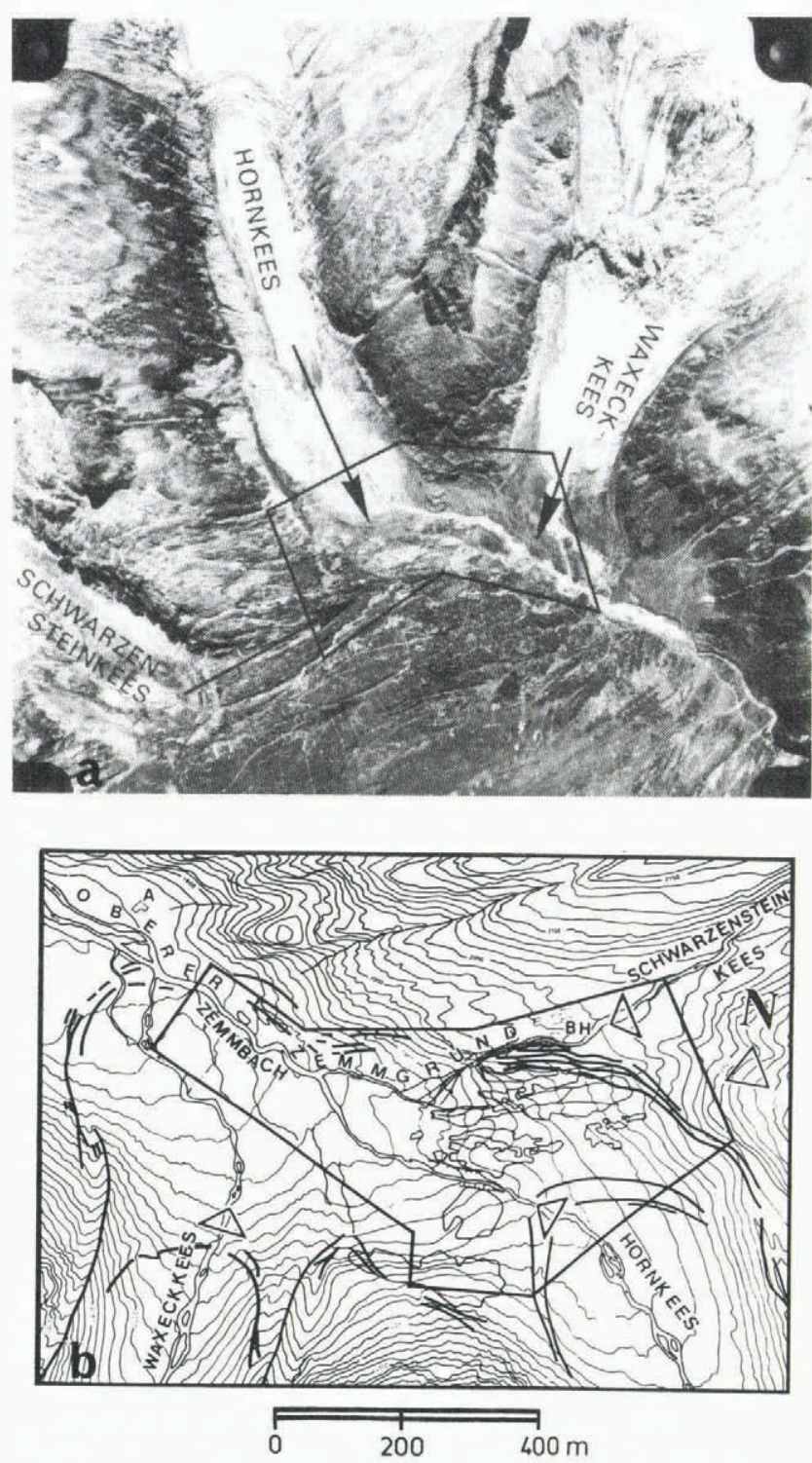

Fig. 2. a. The test area in the Oberer Zemmgrund; aerial photograph Nr. D 13564/54 of the inventory of the forest stand of 1 September 1953.

b. Map of the Oberer Zemmgrund, Zillertal. present studies however includes the central part of the Alpine piedmont glaciation and the Quaternary Alpine mountain ice sheet. The test site is the pro-glacial area of Hornkees, near the Berliner Hütte (Zillertal, Tyrol), at a height of 2000-2100 m a.s.l. (cf. Wintges and Heuberger, 1980[a], p. 14; Wintges, 1982, p. 165 (Figs 1 and 2a and b). As indicated above, the minor glacial features enable us to draw conclusions about the directions of former glacier flow. The final investigations were undertaken in an area where the following pre-conditions were favourable:

1. It is situated in the pro-glacial area of the Hornkees. This area had been passed over by that glacier several times in the post-glacial period. At that time it had merged with a second glacier (Waxeckkees).

2. It is situated in the area of the concordant junction of the late-glacial mergence of these two glaciers with a third one (Schwarzensteinkees). Schwarzensteinkees controlled the flow direction, which was across the post-glacial direction of Hornkees.

As the granite-gneiss in the investigation area was a somewhat homogeneous rock type (Ficker and others, 1980, p. 30-32), it was possible to state the following limitations:

A. In terms of its ice thickness (maximum ice thickness is $150 \pm 50 \mathrm{~m})^{*}$, the extent of post-glacial Hornkees can be limited by corresponding moraines. During late-glacial times there was a confluence with Schwarzensteinkees. During this period the ice of Schwarzensteinkees dictated the flow direction (during Egesen about $300 \mathrm{~m})^{*}$ and pushed the ice of Hornkees aside.

B. The change in the ice-flow direction is therefore directly related to the maximum ice thickness of Hornkees and to a minimum thickness of Schwarzensteinkees (during Egesen the lowest value was $250 \pm 50 \mathrm{~m})^{*}$ - see also Klebelsberg (1935, p. $540)$.

C. From (B) it follows that: (a) crescentic fractures, crescentic gouges, lunate fractures (Sichelwannen), and combined striae in the pro-glacial area of Hornkees can be not only of a post-glacial but also of a late-glacial origin; and (b) for the first time there was the possibility of relating the size of these minor features to the ice thickness.

D. Both systems of minor features which are different in their ice-flow directions are also different in their ages of origin. The older system had already been exposed to weathering and glacial erosion at the time the younger system originated. So perhaps it is possible to evaluate the degree of glacial erosion for the late-glacial and post-glacial periods.

The present study comprised the following details:

a. The development of a method for planning the precise survey of these minor features.

b. The analysis in relation to the surface features (e.g. the ratio of slope of the terrain in relation to the glacier-flow directions).

c. The study of the sizes of these minor features in relation to the different glacier-flow directions (hence to different older and thicker glaciers).

* Personal communication from Professor H. Heuberger, Salzburg. 
d. The mapping of existing striae for determining the different glacier-flow directions and, as far as possible, for the interpretation of the chronological order of their origin.

e. The reconstruction of the possible stream lines of the merged "Zemmgrund glaciers", interpreted from the directions of the striae, crescentic fractures, crescentic gouges, and lunate fractures (Sichelwannen).

f. The determination of the degree of denudation by these minor features as referred to a definable area.

g. The number of criteria of the crescentic fractures and crescentric gouges for mathematical and mechanical model studies and calculations, so that the conditions for their origin could be derived.

h. The chronological order of the origin of crescentic fractures and crescentic gouges, as far as was possible from these detailed studies.

\section{THE FORMS INVESTIGATED}

\section{Combined striae (Fig. 3)}

Each of these striae is rough and not polished to its maximum depth. This means that the rock surface was destroyed at the point of contact between a rock in the

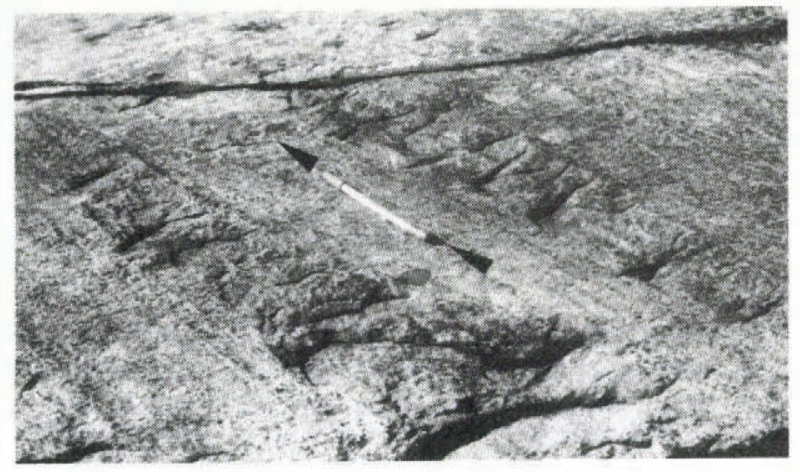

Fig. 3. Type of combined striae in the pro-glacial area of Hornkees near Berliner Hütte; the tip of the pencil indicates the ice-flow direction.

rock-ice mixture and the bedrock. Minute rock particles are first loosened and detached from the bedrock when it is fractured (removal of the rock under pressure of the ice on the surface of the bedrock).

According to the size and kind of rock scraping the bedrock surface, and the pressure of the ice on it, the striae can vary both in depth and breadth. Deepening of the striae does not occur in a single stage but it most probably takes place in several phases. This is proved by the series of crescentic fractures or crescentic gouges which combined striae have when they attain a sufficient width (cf. Chamberlin, 1888, p. 219-33; Hillefors, 1968, p. 323). On the basis of the present investigations in the Zemmgrund, Zillertal, and in southern Scandinavia, it can be stated that combined striae are on average ten times larger than the usual striae. Furthermore, the investigations have shown that with this type of stria plucking is very clearly effective. The crescentic fractures and the crescentic gouges occur within the striae which are of ten $10 \mathrm{~cm}$ broad and $2 \mathrm{~cm}$ deep, and which are plucked out of the bedrock formation. They take up in their length the whole width of the striae. Whether the processes of abrasion and the breaking out of crescentic gouges take place at exactly the same time cannot be answered. It can be assumed that the former ice-flow direction can be interpreted, in the case of inlaid crescentic fractures, as being in the direction of the concave curvature of the parabola arch or, in case of the crescentic gouges, in the direction of the convex arch. So with the combined striae the former ice-flow direction, at least the last phase, can be determined precisely with the help of the inlaid crescentic fractures and crescentic gouges.

\section{Crescentic fractures and "crescentic grooves"}

Crescentic fractures (Fig. 4) are formed mainly in rocks with a predominant quartz component. In the case of the crescentic fracture, the type of curvature and the lateral
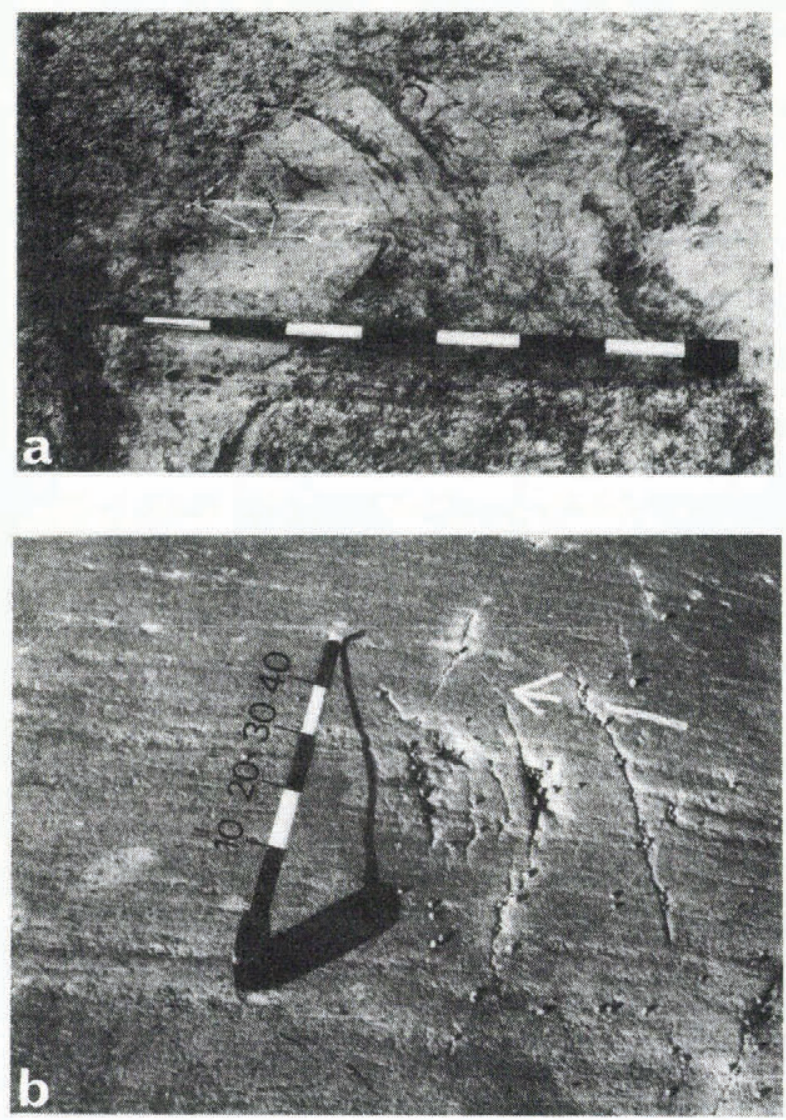

Fig. 4. a. Crescentic cracks in the pro-glacial area of Nigardsbreen.

$b$. Crescentic fractures on the west coast of Sweden (Nötö-Skepphällorna); the black-and-white parts of the measuring tape have a length of $10 \mathrm{~cm}$; the cracks and fractures trend with their parabolas against the ice-flow direction.

continuation of its arch determine whether the parabolic form is maintained or whether the crack is formed only as a flat segment of a parabola. The concave side of the arch generally indicates the ice-flow direction. However, reversed forms have also been described (Schulz, 1967, p. 137; Schwarzbach, 1978, p. 115). I have also discovered them in the Zemmgrund. The crescentic fracture is only visible through enhancement by frost weathering, which causes a widening of the microscopically fine hairline crack. Whereas in the case of the crescentic fracture there is no substantial loss to the bedrock (at most, microscopically small), the "crescentic groove" is a real fracture form which can be compared with the crescentic gouge. This fracture form of the "crescentic groove" has already been observed by Schulz (1962, p. 1103) in Scandinavian detritus. My studies have revealed that the fracture form of the "crescentic groove" subsequent to its origin can only be explained by the process of frost weathering. In the case of the "crescentic 
groove", widening of the microscopically fine crack takes place only with the aid of several "glacier loadings" and frost weathering. Only under favourable conditions and through the effects of the frost-weathering process does it achieve the form of the "crescentic groove". My observations have shown that loss of the bedrock occurs in several phases (mineral by mineral). This does not occur with larger fragments as in the fracture forms. They do not have the typical features of primary and secondary fractures (cf. Gilbert, 1906, p. 306) as with crescentic gouges.

\section{Crescentic gouges (Fig. 5)}

In contrast to the crescentic fracture, the crescentic gouge (negative form) generally has the convex side of its arch form pointing towards the ice-flow direction. But again reversed forms are also possible and can be of a completely different origin (Andersen and Sollid, 1971, p. 4). The fracture form itself can acquire distinctive forms (Wintges and

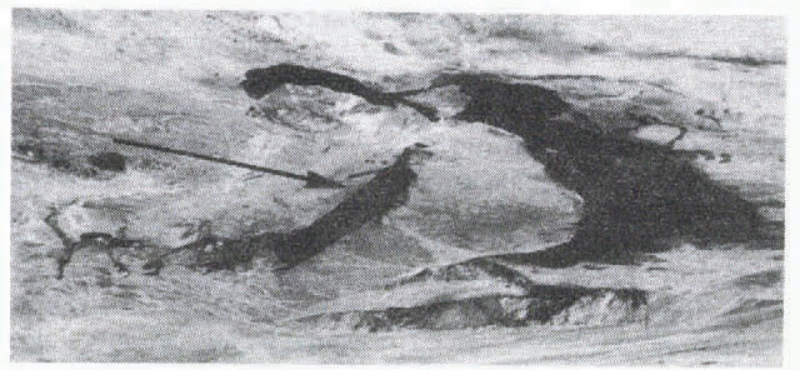

Fig. 5. Crescentic gouge (negative and positive forms) in the confluence area of Hornkees and Schwarzensteinkees south of the Berliner Hütte; the parabola trends into the ice-flow direction.

Heuberger, $1980[$ b], p. 163). Generally the primary fracture starts flat (low incidence with an angle less than $28^{\circ}$ ) and is restricted by the steeper secondary fracture. The latter is inclined at more than $61^{\circ}$. The course of the fracture itself is, in contrast to the crescentic fracture, less regularly formed. But, even in the case of extreme homogeneities in the bedrock, such as a band of quartz in a granite-gneiss, contrary to all expectations, no effect can be observed on the course of the fracture. In any case, the arch form is achieved. Positive forms of crescentic gouges found in situ prove that they were not initially formed as a fracture form. The reason is that several physical processes occur before the final definitive form is produced. Crescentic gouges are probably caused initially by similar compression and shear stress as in the case of crescentic fractures. As far as the further formation of the fracture is concerned, both plucking and frost weathering must be considered. Thus, the crescentic gouge differs from the "crescentic groove" and the crescentic fracture. Its mechanical origin is that of a typical fracture form. It must be said that this occurs when rigid materials such as rock or glass are loaded. Therefore, the form of the crescentic gouge has both a primary and a secondary fracture (cf. Wintges and Heuberger, 1980[b], p. 162-64). The primary fracture is the surface fracture which develops after formation of a crack, as in the case of crescentic fracture formation, by frost weathering or some form of mechanical loading at the glacier bed. In the case of the secondary fracture, there is comparison with a "residual fracture" which commences at the end of the fracture preceding the primary surface fracture (see Wintges, 1984, p. 87-91).

\section{Lunate fractures (Sichelwannen)}

Ljungner (1930) has studied lunate fractures (Fig. 6) extensively on the west coast of Sweden and has described all of their form types. The reconstruction of the ice-flow direction is related to one of the crescentic fractures. The concave direction of the arch therefore indicates the ice-flow direction. Since it is a question of a glacial erosion form in the case of the lunate fracture, in contrast to the forms described above, and since the lunate fracture is rarely found in the research area of Zemmgrund, the following text does not deal with this form type.

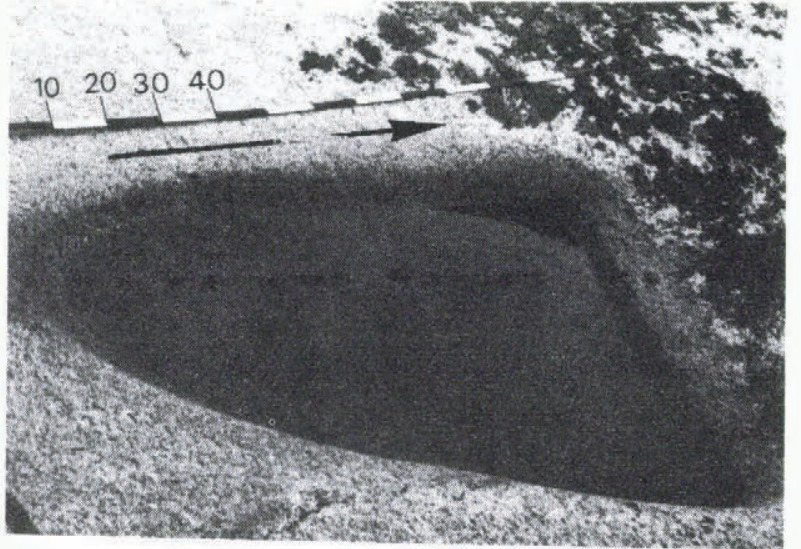

Fig. 6. Lunate fracture on the west coast of Sweden (Nötö); the black-and-white parts of the measuring tape have a length of $10 \mathrm{~cm}$; the parabola trends against the ice-flow direction.

\section{INSTRUMENTATION AND FIELD MEASUREMENTS}

The above-mentioned relevant works contain only general systematic observations with a limited number of measurements. Within the framework of the research project, it was possible to map the minor features covering the whole test site of the pro-glacial area of Hornkees and Waxeckkees. The need for accuracy and thoroughness, however, could not be met by the method which had been used during previous investigations of the minor features.

For this reason the method of close-range photogrammetry was applied. Two camera types were used:

a. The Wild C-40 wide-angle stereometric camera (Fig. 7) with a special tripod for vertical photographs.

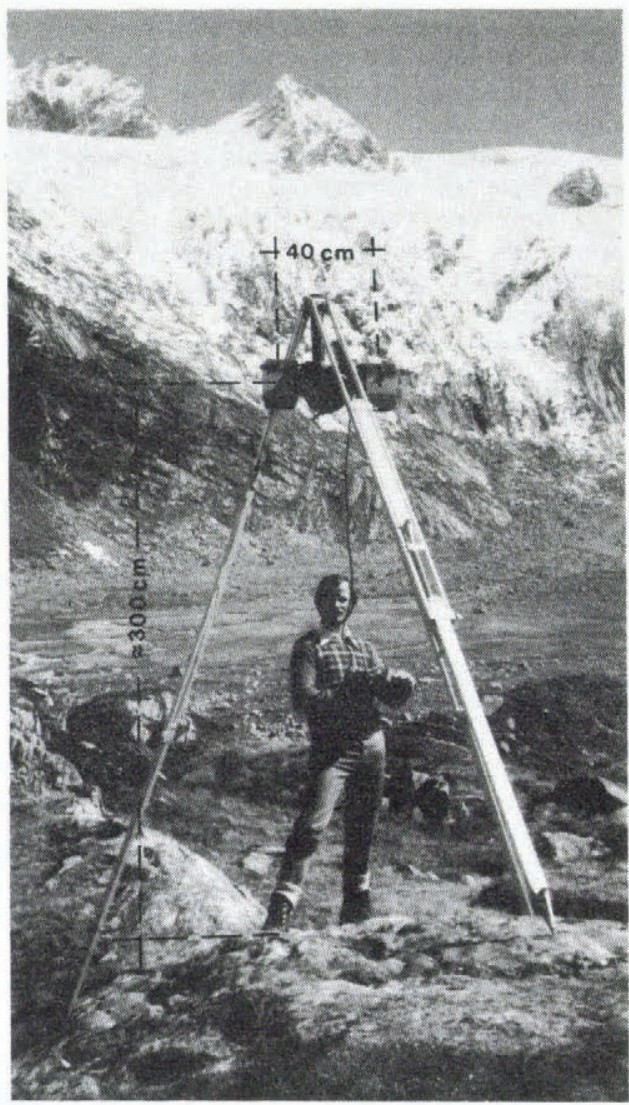

Fig. 7. The Wild $C-40$ wide-angle stereometric camera with a special tripod; in the pro-glacial area of Schwarzensteinkees. 


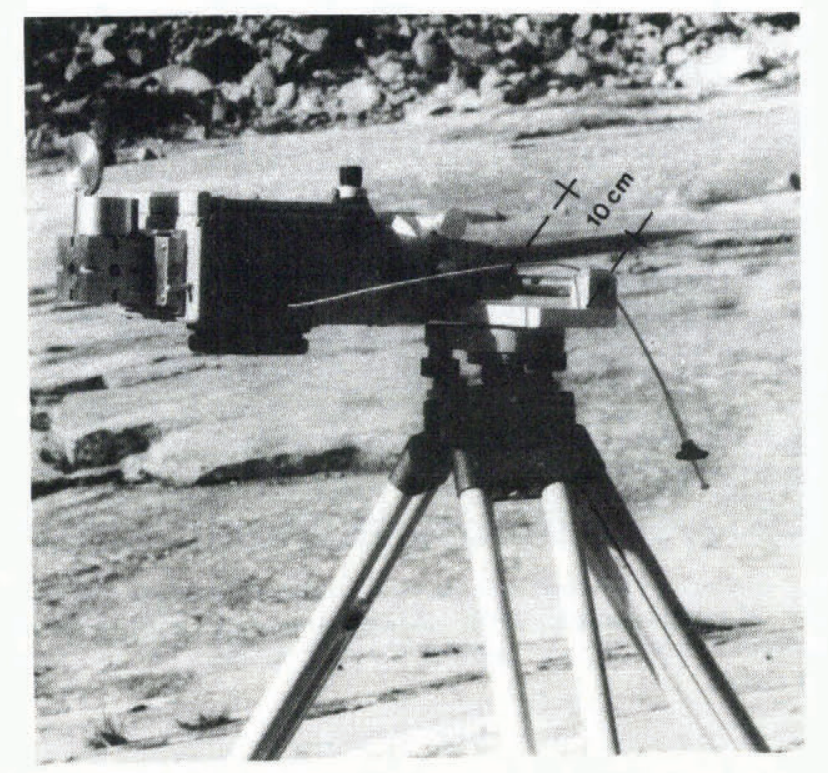

Fig. 8. The Zeiss TMK-6 terrestrial camera with a special carriage; south of the Berliner Hütte.

b. The Zeiss TMK-6 terrestrial camera (Fig. 8) with a special carriage for an adapter cube for two vertical photographs from one viewing point.

With the Wild C-40 camera it is possible to take vertical photographs from a height of $3-4 \mathrm{~m}$. The length of the base is $40 \mathrm{~cm}$. The area covered by the photograph taken depends on the height of the camera; in this case it had an original area of $2.5-3.5 \mathrm{~m}^{2}$. With a photograph height of $3 \mathrm{~m}$ the accuracy in the height is $\mathrm{d} h= \pm 3 \mathrm{~mm}$ for positions $\mathrm{d} l= \pm 0.3-0.5 \mathrm{~mm}$ (Wintges and Heuberger, 1980 [a], p. 15 and 16). One picture has a pair of stereophotographs on glass plates with dimensional stability. The plate size of each glass plate is $6 \mathrm{~cm} \times 9 \mathrm{~cm}$. This camera was used for photographs covering the whole test area.

For the photographs of the combined striae, the Zeiss TMK-6 camera was used. With this kind of camera, it is not possible to have a synchronous exposure for both photographs because, in contrast to the Wild C-40 camera, it consists of only one camera. However, since the minor glacial features are static, it was possible to take two photographs from one viewing point using a special carriage built for the purpose (Wintges, 1982, p. 167). The height of the photograph was $1 \mathrm{~m} \pm 15 \mathrm{~cm}$ and the length of the base from one photograph to the other was $10 \mathrm{~cm}$. The accuracy of this camera is comparable with that of the Wild C-40 camera. Here again glass plates were used but with a size of $9 \mathrm{~cm}$ by $12 \mathrm{~cm}$.

The glacially moulded rock surface of the pro-glacial area of Hornkees and Waxeckkees covers about $100000 \mathrm{~m}^{2}$; approximately $90000 \mathrm{~m}^{2}$ was covered by a grid of $20 \mathrm{~m}$ by $30 \mathrm{~m}$ test sites; the remaining $10000 \mathrm{~m}^{2}$ were covered by single photographs. At least one photograph was taken of each grid rectangle. Therefore, we took 160 pairs of stereophotographs with the Wild C-40 camera (in the summers of 1977 and 1979). With these photographs it was possible to record 3500 crescentic fractures and 8000 crescentic gouges. In the summer of 1981,80 pairs of stereophotographs were taken with the Zeiss TMK-6 terrestrial camera. In doing so, we recorded 34 combined striae with about 600 miniature crescentic gouges. Each pair of stereophotographs contains a scale for the calculation of the photograph scale and a north direction marker (Fig. 9).

\section{CLOSE-RANGE PHOTOGRAMMETRIC INTERPRETATION AND ITS PROCESSING}

We relied on the simplified description of the minor features by Ljungner (1930, p. 287), and for rational reasons we stylized the minor features. Because standard sizes were chosen, the various forms could be measured and quantified by their forms and their positions. Fundamentally, every pair of stereophotographs can be digitized as single points. This factor was exploited and during the interpretation of the pairs of stereophotographs with the first-order Zeiss Planimat D2 equipment the photographs were adequately digitized. We had to proceed step by step. First, the pairs of photographs were rectified (removal of distortion) so that they could be viewed stereoscopically and interpreted. Subsequently, each photograph was given a local coordinate system with a coordinate origin at the centre point. The interpretation of the forms followed and this was done by using contour lines and point by point. For reasons of time and expense, it was necessary to use this type of processing throughout. Thus, the crescentic cracks were given three characteristic points and the crescentic gouges five characteristic points with the coordinates $x, y$ (horizontal: position) and $z$ (vertical: depth). At the same time the arch forms were resolved into triangles (Figs 10 and 11).

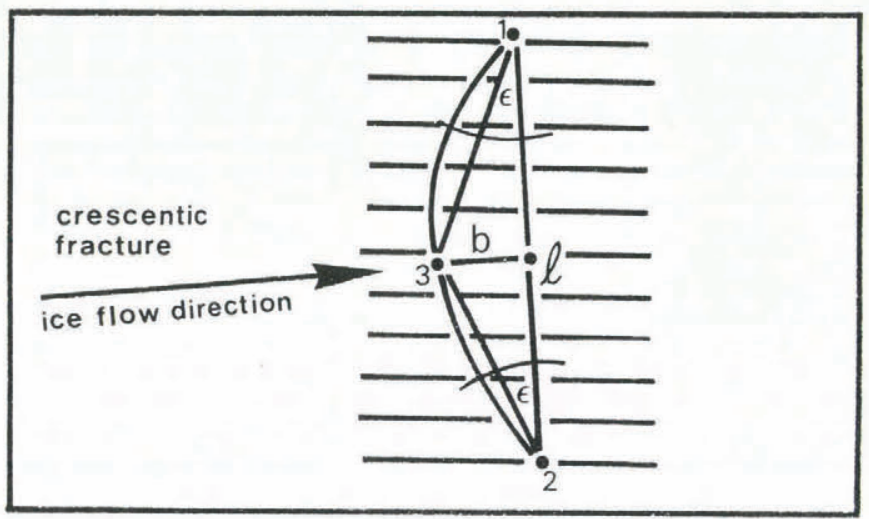

Fig. 10. Sketch of a crescentic fracture as a parabolic and a triangular form.
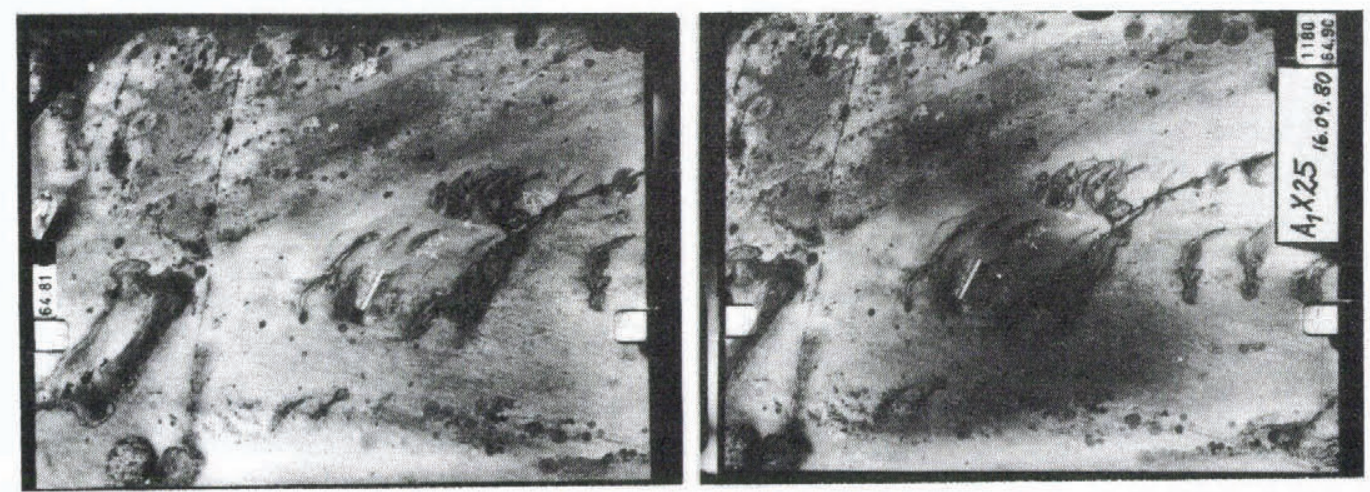

Fig. 9. Pair of stereophotographs taken by the Wild C-40 stereometric camera. The photographs have a scale and a directional marker (north). 


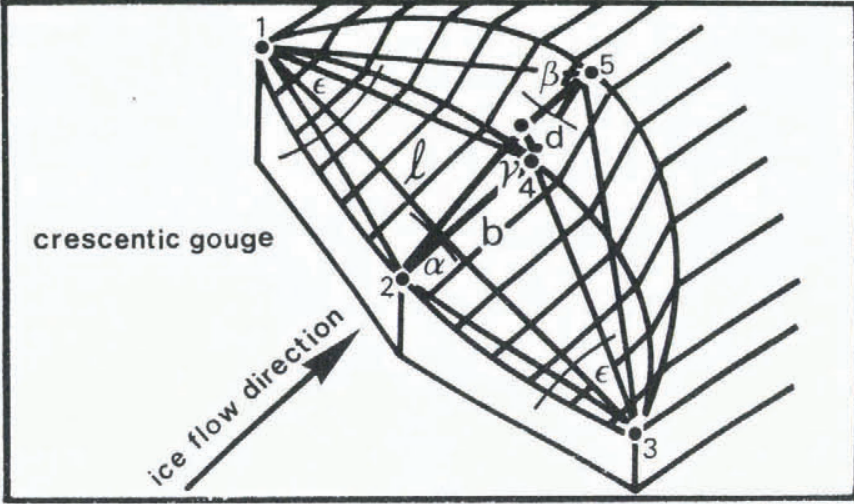

Fig. 11. Diagram of a crescentic gouge similar to that in Figure 10.

Processing still continued during the interpretation and the registered points of the various forms were automatically transferred on to punched cards (see also Wintges, 1982, p. 172). After preparation of the measured data, calculation and drawing programmes enabled calculations and descriptions of the individual parameters of the minor glacial features to be made. The individual parameters are (cf. Wintges and Heuberger, 1980[a], p. 16 and 17, [b], p. 160 and 161):

a. Length $(l)$ and breadth $(b)$ of crescentic fractures and crescentic gouges.

b. Depth $(d)$ of crescentic gouges.

c. Angles $\alpha$ and $\beta$ of the fracture planes of crescentic gouges.

d. Opening angle $\epsilon_{1}$ and $\epsilon_{2}$ of crescentic fractures and crescentic gouges.

e. Directional angles of the flow direction for every minor glacial feature (investigated by discrimination analysis; cf. Wintges and Heuberger, 1980[a], p. 20).

f. Angle $y$ for the terrain slope.

For an illustration of the interpretations, see the following descriptions (Figs 12, 13, and 14).

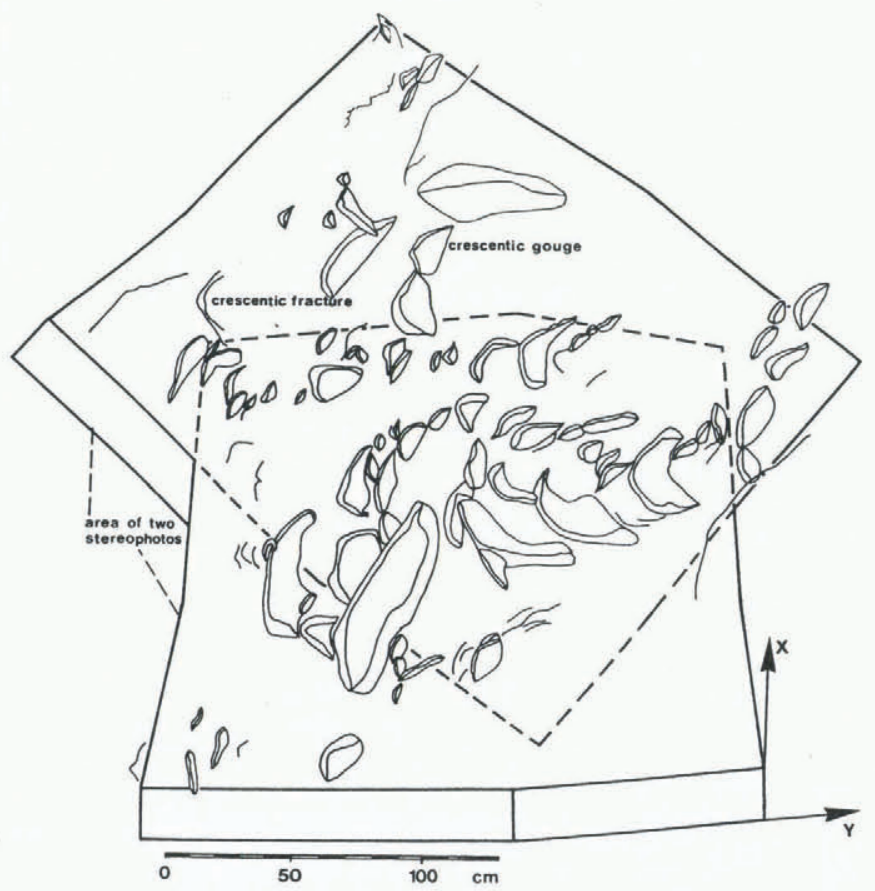

Fig. 12. The interpretation of two pairs of stereophotographs. The crescentic cracks and crescentic gouges are drawn as "isohypses".

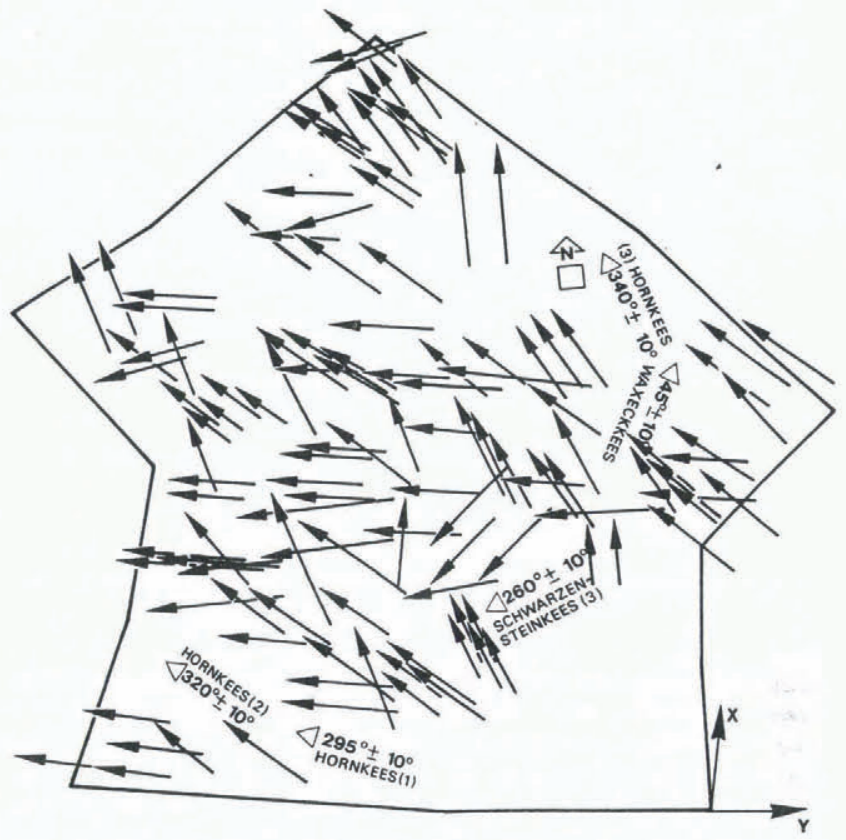

Fig. 13. An example of the analysis of different directions of microforms giving the interpretation of the flow directions of earlier glaciers.

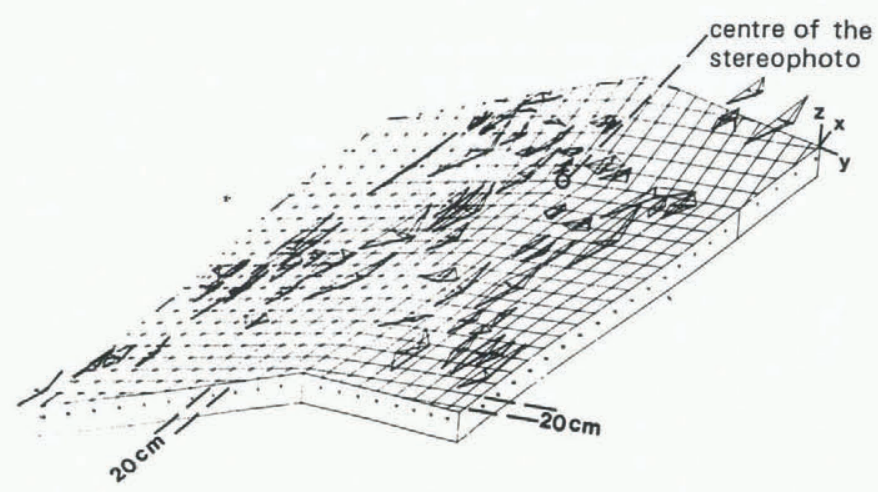

Fig. 14. A "block diagram" made by computer; it is a reduction of the original which had a scale of $1: 5$ (cm). The diagram shows the microforms in three dimensions. With this kind of diagram it was possible to reconstruct the morphological conditions at the test sites.

\section{RESULTS}

\section{Combined striae}

In the research area only striae of this type derived from the various flow directions of Hornkees are preserved. This observation also agrees with the conclusions of the general mapping of striae, i.e. that the post-glacial advances of Hornkees have erased all that resulted from Schwarzensteinkees' former flow directions.

In the Zemmgrund, the length of the combined striae varies between 0.5 and $2 \mathrm{~m}$. The width of these striae can be anything from 4 to $8 \mathrm{~cm}$ and their depth is $0.1-0.8 \mathrm{~cm}$. From Table $\mathrm{I}$ it is clear that the width of the crescentic gouges which lie within them is generally the width of such striae. The exceptions are invariably towards the middle of combined striae, where they become broader and where there is sometimes a "blasting" of the edge of striae by a crescentic gouge (Table I).

Generally, the following can be stated: the length of combined striae varies so much and is so unpredictable that a description of average values would be meaningless. The same applies to the width of the striae. Also, the number of crescentic gouges, like their length $(l)$ and breadth $(b)$, varies greatly in combined striae. Thus average measurement descriptions are pointless. 
TABLE I. LENGTH, BREADTH, AND DEPTH OF COMBINED STRIAE AND THEIR CRESCENTIC GOUGES

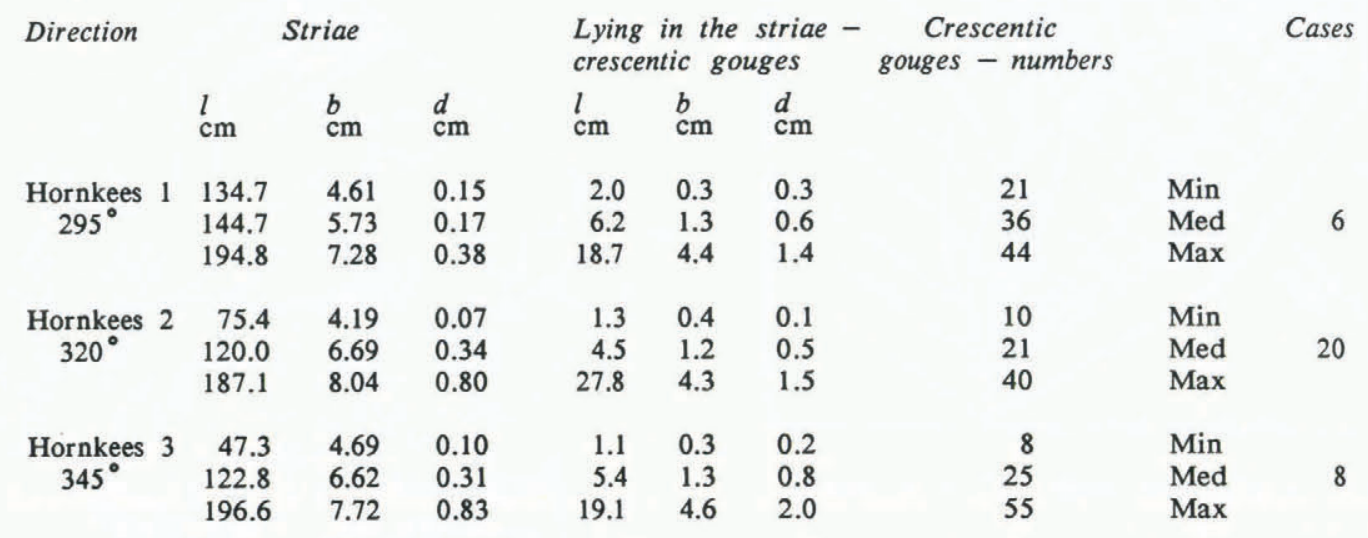

There is, however, one special feature. The crescentic gouges, which are staggered one after the other in combined striae, become longer and deeper in the middle of the series, corresponding to the picture of the striae themselves. As a rule, the striae start off thin and shallow, reaching their maximum width and depth in the centre, and terminating in a similar manner to the beginning. A quantitative comparison of the depth of striae, like the depth of the crescentic gouges of forms which lie in the striae, is possible and could be useful.

\section{Crescentic cracks and crescentic gouges}

The relation between directions of crescentic fractures and crescentic gouges in the test areas, which was monitored by computer with the aid of discrimination analysis, revealed that there are three directions for Schwarzensteinkees and Hornkees. Moreover, individual directions may show discrepancies of $\pm 10^{\circ}$.

Thus, $66.5 \%$ of the crescentic cracks were mainly due to post-glacial but also late-glacial advances of Hornkees. $7.5 \%$ were probably post-glacial but perhaps also due to late-glacial advances of Waxeckkees, and $25.3 \%$ were due to late-glacial advances of Schwarzensteinkees. $0.7 \%$ could not be identified. By contrast, $55.7 \%$ of the crescentic gouges recorded at the test sites belonged to flow directions of Hornkees. They were joined by $7.5 \%$ of crescentic gouges, which were associated with combined striae. Nevertheless, $27.9 \%$ of all crescentic gouges were due to the flow directions of Schwarzensteinkees and $5 \%$ to those of Waxeckkees. $3.8 \%$ of the crescentic gouges showed no definite flow directions and therefore could probably be attributed to variations in ice flow at the base of the glacier (Table II; Fig. 15a-c).

The crescentic cracks and crescentic gouges of the lateglacial Schwarzensteinkees' flow directions are on average marginally but very definitely larger than those of the Hornkees' and Waxeckkees' flow directions. The difference in length $(l)$ is on averge up to $15 \%$ smaller than for those of Hornkees but it can also be up to $30 \%$. In the case of the Waxeckkees' forms, differences of up to $60 \%$ smaller can be measured. Similar values are revealed for crescentic fractures. These obvious differences (Fig. 15a-c) are also shown in the frequency distributions of the crescentic gouges' lengths. We discovered a greater frequency below $10 \mathrm{~cm}$ in the case of the Hornkees' and Waxeckkees' forms. In the case of Schwarzensteinkees' forms, however, such a frequency is only shown at a size of $10-25 \mathrm{~cm}$. This statement is even more remarkable when one consideres the fact that a large number of the smaller forms due to Schwarzensteinkees have been undoubtedly abraded by the post-glacial advances of Hornkees and Waxeckkees. This is especially valid when considering the depth details of the crescentic gouges. On average, forms due to Schwarzensteinkees have certainly been more abraded by the post-glacial advances of Hornkees (at least 15) than the forms due to Hornkees. Thus, the relative sizes of Schwarzensteinkees, Hornkees, and Waxeckkees can be very clearly differentiated. This is especially marked at the margins of the pro-glacial area of Hornkees, where there was the least ice movement of Hornkees. We are now at the point where we can discover the reason for these size differences. Our knowledge of the test area led to the following interdependent conclusions:

a. The glaciers of the late- and post-glacial periods had different ice thicknesses.

b. There was different shear and stress in the glaciers.

c. The grain-size of the material that had been transported as ground moraine may also be of importance.

d. The length of the period of loading on the bedrock surface by overlying glacier ice is important.

TABLE II. LENGTH, BREADTH, AND DEPTH OF CRESCENTIC CRACKS AND CRESCENTIC GOUGES OF HORNKEES, SCHWARZENSTEINKEES, AND WAXECKKEES

\begin{tabular}{|c|c|c|c|c|c|c|c|c|}
\hline \multirow{2}{*}{$\begin{array}{l}\text { Locality } \\
\text { (Zillertal) }\end{array}$} & \multicolumn{3}{|c|}{ Crescentic fractures } & \multicolumn{3}{|c|}{ Crescentic gouges } & \multirow[t]{2}{*}{ Cases } & \\
\hline & $l$ & $b$ & $d$ & $l$ & $b$ & $d$ & & \\
\hline \multirow[t]{3}{*}{ Hornkees } & 2.7 & 0.1 & & 2.5 & 0.2 & 0.1 & & Min \\
\hline & 7.9 & 2.6 & 2327 & 15.9 & 3.6 & 1.9 & 4457 & Med \\
\hline & 36.7 & 11.9 & & 97.2 & 35.3 & 17.4 & & $\operatorname{Max}$ \\
\hline \multirow[t]{3}{*}{ Schwarzensteinkees } & 2.4 & 1.1 & & 3.1 & 0.4 & 0.1 & & Min \\
\hline & 12.8 & 5.4 & 887 & 18.6 & 4.3 & 1.9 & 2234 & Med \\
\hline & 109.9 & 57.0 & & 145.7 & 34.9 & 28.4 & & $\operatorname{Max}$ \\
\hline \multirow[t]{3}{*}{ Waxeckkees } & 2.3 & 1.0 & & 1.9 & 0.2 & 0.3 & & Min \\
\hline & 19.3 & 9.9 & 261 & 8.9 & 4.1 & 2.1 & 404 & Med \\
\hline & 28.6 & 24.8 & & 49.6 & 20.2 & 35.5 & & $\operatorname{Max}$ \\
\hline
\end{tabular}


SCHWARZENSTEINKEES (A1)SK

proved cases 2234

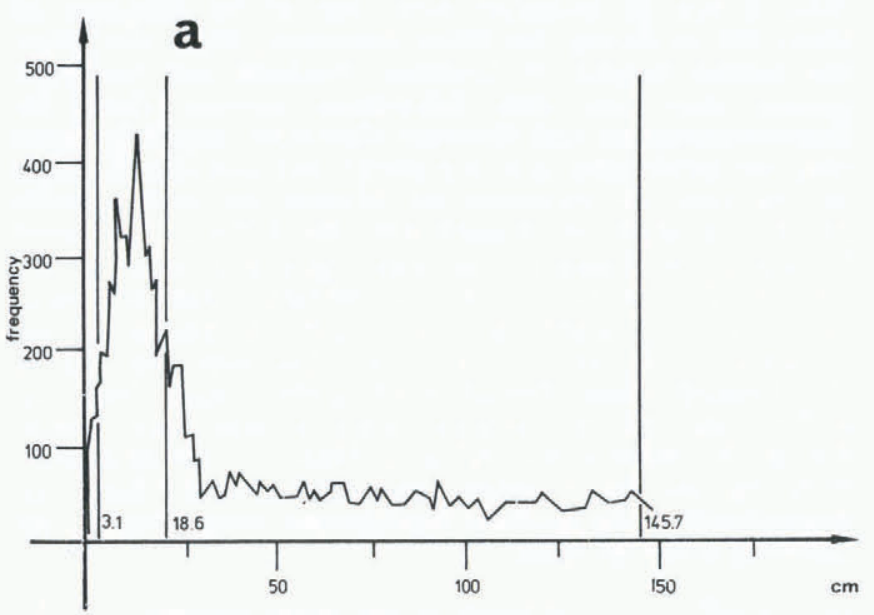

HORNKEES (A1) HK

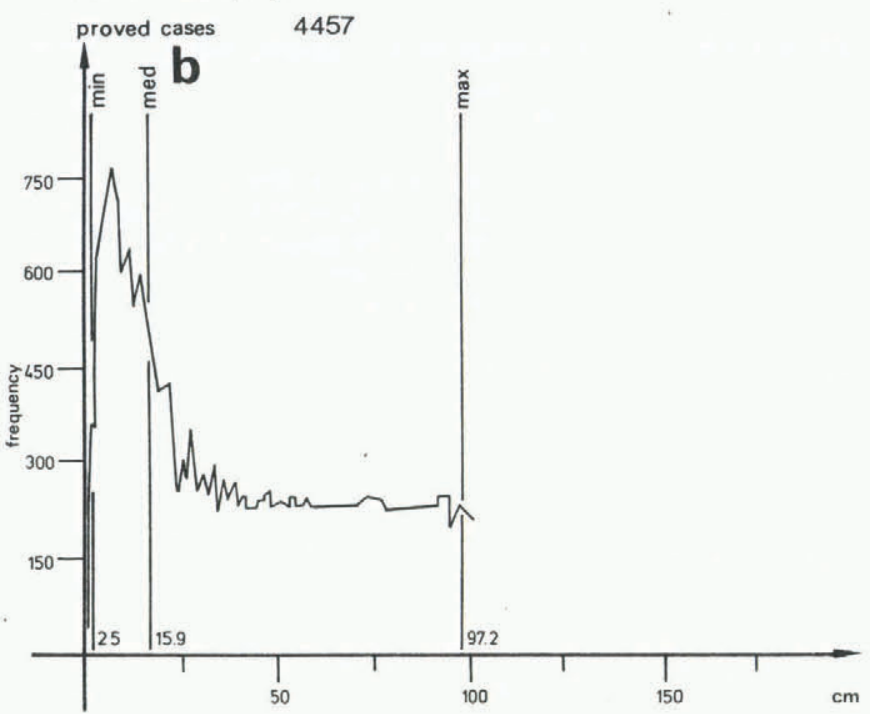

WAXECKKEES (A1) WK

proved cases $\quad 404$

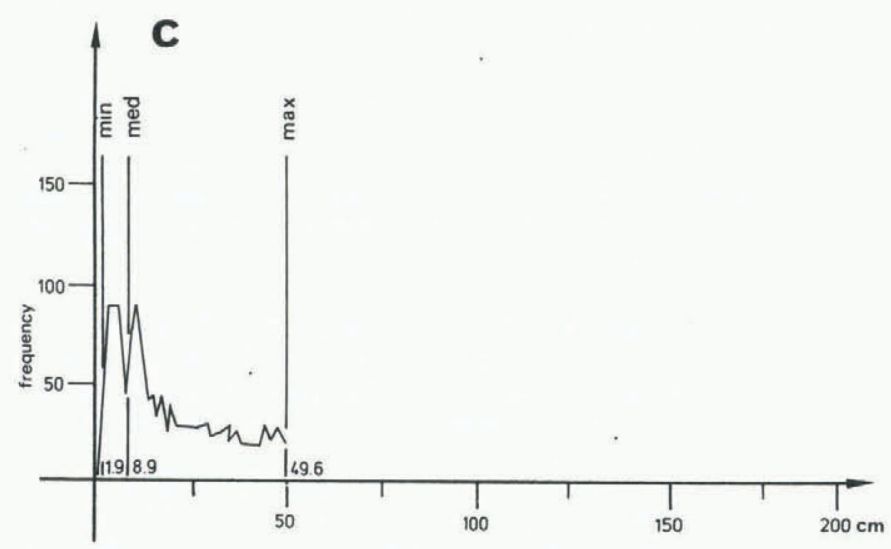

Fig. 15. a. Frequency distribution of three directions of Schwarzensteinkees shown on the length (l: longitudinal side) of crescentic gouges.

b. Frequency distribution of three directions of Hornkees shown on the length ( $l$ : longitudinal side) of crescentic gouges.

c. Frequency distribution of one direction of Waxeckkees shown on the length ( $l$ : longitudinal side) of crescentic gouges.

\section{ANALYSIS OF THE RESULTS}

Analysis of the directions of former glacier flow Striae. Mapping of the striae resulted in a classification which belonged, almost without exception, to the flow direction of Hornkees. Only one small rock surface at the new transformer station of the Berliner Hütte has striae which must be related to a flow direction of Schwarzensteinkees. On the basis of the results of this field work, the few remaining striae on the pro-glacial area of Hornkees-Waxeckkees must be related to a late-glacial direction of Schwarzensteinkees. On the other hand, the numerous relatively fresh striae from directions of Hornkees must be attributed to a post-glacial origin. On the basis of this mapping, it has been shown that on the investigated rock surfaces (160 test sites) there is a $0.6 \%$ coverage for striae of the direction of Schwarzensteinkees and also a $47.3 \%$ coverage for Hornkees' directions.

Series of crescentic fractures and crescentic gouges. As has already been mentioned, crescentic fractures or crescentic gouges are clear evidence for former glacier-flow directions, if they are grouped as a series in one row after another. These particular series are not identical with combined striae which, on the basis of the within-lying series of minor features, indicate special ice-flow directions. As far as series go, there are at least three single forms (median 10; maximum 26) grouped one after the other. In the test area, 227 of these series have been surveyed (of which 81 are Schwarzensteinkees directions and also 146 are Hornkees directions). They vary in their overall length from $37 \mathrm{~cm}$ (min.) to over $300 \mathrm{~cm}$ (median), and up to $1205 \mathrm{~cm}$ (max.). Over the whole test area, with the help of mapping these series, a degree of coverage (for the investigation of possible ice-flow direction) of $28.8 \%$ for Schwarzensteinkees directions, $82.4 \%$ for Hornkees, and $4.8 \%$ for Waxeckkees directions has been achieved.

Crescentic fractures and crescentic gouges. The assignment of directions for crescentic fractures and crescentic gouges was carried out as described above. On the 160 test sites, about 12000 crescentic fractures and crescentic gouges were specified with regard to their ice-flow directions. This analysis enabled a degree of coverage of almost $100 \%$ for all Schwarzensteinkees directions (components of direction of Schwarzensteinkees $1=7.5 \%$, Schwarzensteinkees $2=17.5 \%$, and Schwarzensteinkees $3=98.7 \%$ ), of almost $100 \%$ for all Hornkees directions (components of direction of Hornkees 1 $=61.0 \%$, Hornkees $2=37.0 \%$, and Hornkees $3=99.4 \%$ ), and also $31.0 \%$ for Waxeckkees' direction. These different percentages for the individual flow directions can be deduced from the different spheres of influence of the individual ice movements. The analysis of these directions, which was carried out in different ways, led to a reconstruction of the probable main flow directions of the former ice (at least at the glacier bed).

Examples of possible flow characteristics are shown in Figure 16a-c. Almost 18000 single observations of direction (squares) are generalized (small arrows). The possible boundaries (present moraines from morphological observations) and the main flow directions (large arrows) are hypothetical. With the assistance of many similar figures, it was possible to delimit the flow systems of Schwarzensteinkees, Hornkees, and Waxeckkees. Thus a delimitation of the late-glacial and post-glacial flow systems was achieved (cf. Wintges, 1984, p. 117 and following). This information on directions should be supportive of an examination of the flow pattern and should be achieved by simulation of the flow behaviour of a glacier in a true-to-nature model, and substantiated by research work. At the present time, preliminary investigations are in progress which are sponsored by the Deutsche Forschungsgemeinschaft under the title "flow behaviour of a glacier".

Length of crescentic fractures and crescentic gouges related to ice thickness

It is quite clear from the quantitative investigations that there are two clearly distinguishable main directions (Hornkees and Schwarzensteinkees) which produced different forms at different times. These glacier combinations which 

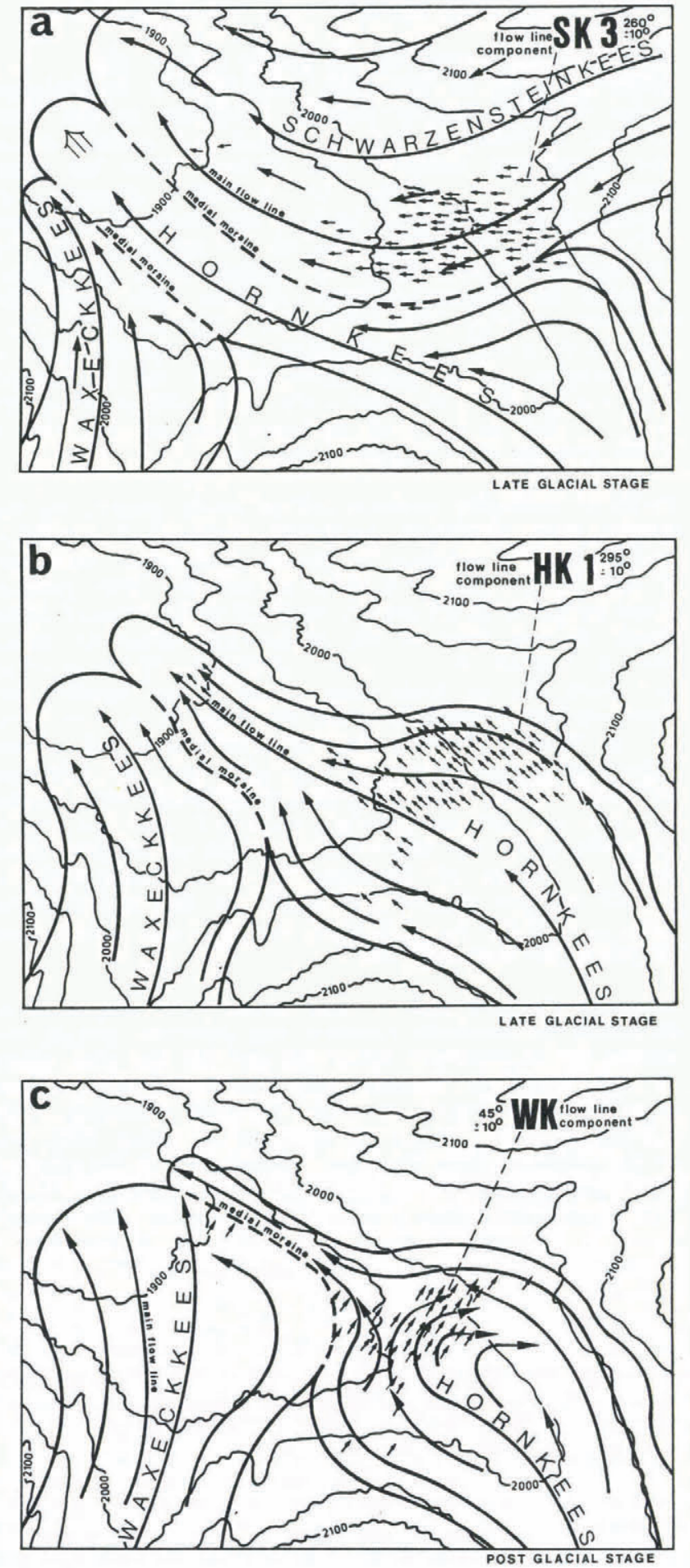

Fig. 16. a-c. Sketches of hypothetical stream lines for former ice movements which were reconstructed from striae, series of crescentic fractures, and crescentic gouges. The small arrows document the ice-flow directions which are constructed from the crescentic fractures and crescentic gouges of 160 stereophotographs. Moraines, the terrain slope, and other morphological details are also considered. a. Schwarzensteinkees; b. Hornkees; $c$. Waxeckkees.

can be distinctly divided into those of Hornkees and Waxeckkees in the post-glacial, and also these two glaciers and Schwarzensteinkees in the late-glacial signify there was a confluence of glaciers with different ice thicknesses. For the post-glacial maxima, Heuberger has stated that from his mapping of the lateral moraines (see above) there was an upper limit of ice thickness of $150 \pm 50 \mathrm{~m}$ over the test sites. On the basis of his mapping of the Egesen lateral moraine in the research area, he showed an ice thickness of about $300 \mathrm{~m}$ for the final late-glacial maximum (cf. Wintges, 1984 , p. 158). According to Klebelsberg (1935, p. 540 ), it can be estimated there was an ice thickness of about $700 \mathrm{~m}$ during the Würm maximum. When one views the median lengths of crescentic fractures and crescentic gouges, there are clear differences between those for Schwarzensteinkees and Hornkees directions, especially when they are subdivided into late-glacial and post-glacial forms in the areas of maximum ice advance for each specific glacier. It must be assumed that the different parameters for stress (ice thickness) and shear (gliding velocity of the ice over the ground) can produce different sizes of cracks in the rock (in particular their length) in relation to the morainic material that is transported. Therefore, the size of the boulders, their frequency of contact with the rock surface, and the ice thickness seem to have been critical during the process (cf. Wintges, 1984, p. 155 and 156). With the aid of a simple physical approach, based on measurements from southern Scandinavian research areas, the following could be valid:
(1) $l=a h^{n}$
$l=$ length of the minor features,
$a=9.3 \times 10^{-4}$
$h=$ ice thickness,
$n=1.5$.
(2) $\tau=C h$
$\tau=$ shear or a tangential force,
$C=\frac{\cos \alpha g A}{A}$,
$\cos \alpha=$ angle of slope,
$p=$ ice density $\left(910 \mathrm{~kg} \mathrm{~m}^{-3}\right)$,
$g=$ earth acceleration $\left(\mathrm{m} \mathrm{s}^{-2}\right)$
$\boldsymbol{\mu}=$ friction,
$A=$ area.

(3) $l=a\left(\frac{T}{C}\right)^{n} \quad n=1.5$,

(4) $l=\frac{a \tau^{2 / 3}}{C^{1}} \quad C^{1}=C^{1.5}$.

(5) $l=\frac{a}{C}{ }^{1} \sqrt{\tau^{3}}$

(6) $l=\frac{a}{C} K \sqrt{D} \quad$ Glen's flow law of ice

(7) $l=9.3 \times 10^{-4} h^{1.5}$

a

The final trend of the curve in Figure 17 can be reached if one assumes that:

a. The value of $2.5 \mathrm{~cm}$ deduced from the frequency diagram for Hornkees flow directions is the minimum for the minor features in the post-glacial with an ice thickness of $30 \mathrm{~m}$ at the north-eastern margin of Hornkees at its maximum post-glacial extent.

b. The value of $7.5 \mathrm{~cm}$ (peak) derived from the frequency diagram for Hornkees and Schwarzensteinkees flow directions is related to an ice thickness of about $300 \mathrm{~m}$ in the Egesen.

c. For the Würm maximum, a median value of $19.1 \mathrm{~cm}$ for minor features associated with Schwarzensteinkees flow directions is related to an ice thickness of about $700 \mathrm{~m}$

\section{SUMMARY}

For the first time, it has been possible to photograph and to analyse quantitatively 12000 crescentic fractures and crescentic gouges with the help of close-range photogrammetry in order to determine glacier maxima, which can be distinguished clearly by their age and ice 


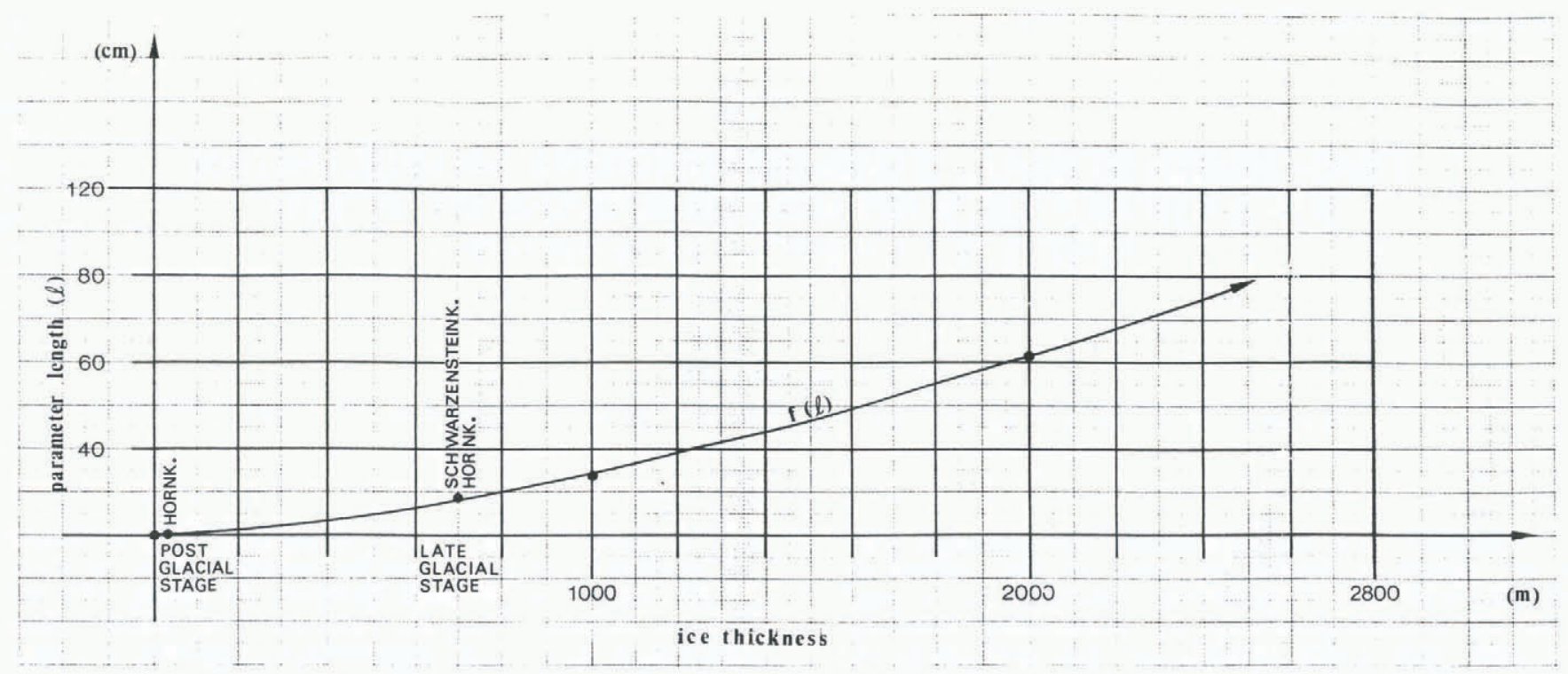

Fig. 17. The calculated curve which shows an unequivocal relation between the parameter length (l) of crescentic gouges and the ice thickness $(h)$ of different glaciers.

thickness. Both with their help and with that of 5500 mapped striae, the ice-flow characteristics for the Upper Zemmgrund during the late-glacial confluence of Schwarzensteinkees and Hornkees, and also for the post-glacial confluence of Hornkees and Waxeckkees could be deduced. It can also be shown that there is apparently a direct correlation between the length of the crescentic fractures or crescentic gouges and the ice thickness (late-glacial and post-glacial).

\section{ACKNOWLEDGEMENTS}

The research in the Zemmgrund, Zillertal, Tyrol, has been run as a project of the Deutsche Forschungsgemeinschaft (DFG) under the title "microforms of glacial erosion". Partners in this project were the following institutes: Professor Dr H. Heuberger, Geographische Institute der Universität Salzburg; Professor Dr W. Hofmann, Institut für Photogrammetrie und Topographie der Universität Karlsruhe, Fakultät für Bauwesen und Vermessungswesen; Professor Dr G. Sonntag, Lehrstuhl C für Mechanik und Spannungsoptik der Technischen Universităt München; Professor $\mathrm{Dr}$ T.H. Erismann der Eidgenössischen Materialprüfungs- und Versuchsanstalt für Industrie, Bauwesen und Gewerbe, Zürich. For financial aid, I wish to thank specially the DFG and the Kommission für Glaziologie, Bayerischen Akademie der Wissenschaften, München (Dipl. Meteor. O. Reinwarth).

\section{REFERENCES}

Andersen, J.L., and Sollid, J.L. 1971. Glacial chronology and glacial geomorphology in the marginal zones of the glaciers, Midtdalsbreen and Nigardsbreen, south Norway. Norsk Geografisk Tidsskrift, Bd. 25, Ht. 1, p. 1-38.

Chamberlin, T.C. 1888. The rock-scorings of the great ice invasions. U.S. Geological Survey. Annual Report, 7th, 1885-86, p. 147-248.

Ficker, E., and Weber, E. 1981. Auf den Spuren der Gletscher-oder-Untersuchungen zum Problem der Rissentstehung an Felsoberflächen. (In 5. Gesa-Symposium. Symposium Nürnberg, 14.-15. Mai 1981. Düsseldorf, VDI-Verlag (Verlag des Vereins Deutscher Ingenieure), p. 89-96. (VDI-Berichte 399.))

Ficker, E., and others. 1980. Ansätze zur mechanischen Deutung der Rissentstehung bei Parabelrissen und Sichelbrüchen auf glazial geformten Felsoberflächen, by E. Ficker, G. Sonntag, and E. Weber. Zeitschrift für Gletscherkunde und Glazialgeologie, Bd. 16, $\mathrm{Ht} .1$, p. 25-43.
Gilbert, G.K. 1906. Crescentic gouges on glaciated surfaces. Bulletin of the Geological Society of America, Vol. 17, p. 303-16.

Harris, S.E., jr. 1943. Friction cracks and the direction of glacial movement. Journal of Geology, Vol. 51, p. 244-58.

Hillefors, A. 1968. Die würmzeitlichen Eisbewegungen und der Verlauf der Deglaziation im Kattegat und im südöstlichen Skagerrak. Meddelelser fra Dansk Geologisk Forening, Bd. 18, Ht. 3-4, p. 315-43.

Johnson, C.B. 1976. Characteristics and mechanics of formation of glacial arcuate abrasion cracks. Dissertation Abstracts International, B., Vol. 36, No. 11, p. 5476-B.

Klebelsberg, R.v. 1935. Geologie von Tirol. Berlin, Borntraeger.

Ljungner, E. 1930. Spaltentektonik und Morphologie der schwedischen Skagerrak-Küste. Teil III. Die Erosionsformen. Bulletin of the Geological Institution of the University of Upsala, Vol. 21, p. 255-478.

Rastas, J., and Seppälä, M. 1981. Rock jointing and abrasion forms on roches moutonnées, SW Finland. Annals of Glaciology, Vol. 2, p. 159-63.

Schulz, W. 1962. Sichelförmige Marken auf Quarzitgeschieben von Feldberg in Mecklenburg und Halle (Saale). Geologie (Berlin), Bd. 11, p. 1102-06.

Schulz, W. 1967. Über glazigene Schrammen auf den Untergrund und sichelförmige Marken auf Geschieben in Norddeutschland. Geographische Berichte, Bd. 43, Ht. 2, p. $125-42$.

Schwarzbach, M. 1978. Glazigene Sichelmarken als Klimazeugen. Eiszeitalter und Gegenwart, Bd. 28, p. 109-18.

Wintges, T. 1982. Untersuchungen an Kleinformen der Glazialerosion (Sichelbrüche, Parabelrisse) mit Hilfe der Nahbereichsphotogrammetrie und der computergestützten Verarbeitung der Messdaten. Zeitschrift für Geomorphologie, Neue Folge, Supplementbd. 43, p. 161-81.

Wintges, T. 1984. Untersuchungen an gletschergeformten Felsflächen im Zemmgrund/Zillertal/Tirol und in Südskandinavien. Salzburger Geographische Arbeiten, Bd. 11.

Wintges, T., and Heuberger, H. 1980[a]. Parabelrisse, Sichelbrüche und Sichelwannen im Vereinigungsbereich von zweier Zillertaler Gletscher (Tirol). Zeitschrift für Gletscherkunde und Glazialgeologie, Bd. 16, Ht. 1, p. 11-23.

Wintges, T., and Heuberger, H. 1980[b]. Untersuchungen an Parabelrissen und Sichelbrüchen im Zemmgrund (Zillertal) und über die damit verbundene Abtragung. Zeitschrift für Gletscherkunde und Glazialgeologie, Bd. 16, Ht. 2, p. 157-70. 